\title{
ONSET OF FLOODING DAN FENOMENA HYDRAULIC JUMP LOOK LIKE DALAM PIPA VERTIKAL
}

\author{
MAHMUDDIN, ${ }^{1}$ SAMSUL KAMAL, ${ }^{2}$ INDARTO, ${ }^{3}$ DAN PURNOMO ${ }^{4}$ \\ 1 Jurusan Teknik Mesin Fakultas Teknik, Universitas Muslim Indonesia \\ 2,3,4 Jurusan Teknik Mesin dan Industri, Universitas Gadjah Mada \\ E-mail: mahmud_umitek@yahoo.com
}

\begin{abstract}
ABSTRAK
Percobaan telah dilakukan pada aliran berlawana arah udara dan air di pipa diameter 24 mm. Alur pengamatan, pengukuran tekanan gradien dan ketebalan film dilakukan di air Reynolds numbers (Re ${ }_{L}$ ) yang bervariasi 322, 465, 630 dan 709 dikombinasikan untuk udara injeksi dengan kecepatan dari 1,845 m/s sampai 6,148 m/s pada jarak $400 \mathrm{~mm}$, $1600 \mathrm{~mm}$ dan $2200 \mathrm{~mm}$ dari saluran masuk air. Data menunjukkan bahwa gradien tekanan dan ketebalan film tidak meningkatkan lumayan sampai sebelum terjadinya banjir. Jika tidak, propagasi gelombang di permukaan aliran film dari bagian bawah saluran masuk udara akan meningkatkan ketebalan film secara bertahap dan tekanan gradien dengan cepat ketika kondisi banjir. Ketebalan film yang meningkat secara bertahap diindikasikan sebagai tampilan fenomena hydraulic jump look like.
\end{abstract}

Kata kunci: film thickness characteristics, hydraulic jump look like, onset of flooding

\begin{abstract}
Experiments have been conducted on countercurrent flow of air and water in pipe of $24 \mathrm{~mm}$ diameter. Flow patterns observations, measurement of the pressure of gradient and film thickness were conducted at water Reynolds numbers (Re ${ }_{L}$ ) are varied 322, 465, 630 and 709 combined to injected air with velocity from $1.845 \mathrm{~m} / \mathrm{s}$ to $6.148 \mathrm{~m} / \mathrm{s}$ at a distance of 400 $\mathrm{mm}, 1600 \mathrm{~mm}$ and $2200 \mathrm{~mm}$ from the water inlet. The data showed that the pressure gradient and film thickness did not increase appreciably until just before the onset of flooding. Otherwise, wave propagation in surface the film flow from the bottom of air inlet would be increasing film thickness gradually and pressure gradient quickly when flooding conditions. Increasing film thikcness gradually indicated as phenomenon hydraulic jump look like.
\end{abstract}

Key words: film thickness characteristics, hydraulic jump look like, onset of flooding

\section{PENDAHULUAN}

Batas aliran berlawanan arah (counter-current flow limitation) terjadi bila kecepatan aliran air yang mengalir ke bawah dan udara mengalir ke atas melebihi harga kritisnya, maka sebagian air akan terangkat ke atas searah dengan aliran udara, fenomena ini disebut onset of flooding. Fenomena flooding dan karakteristik aliran dapat mempengaruhi kinerja peralatan-peralatan industri seperti kondensor, evaporator, kolom destilasi, reaktor kimia gas cair. Peristiwa flooding akan sangat berbahaya bila terjadi pada sistem pendingin reaktor nuklir. Bila inti reaktor menjadi kering sebagian atau keseluruhan, kemudian diusahakan pendinginan dari atas menggunakan air dingin yamg diinjeksikan dari Emergency Core Cooling (ECC). Bila uap hasil pendidihan (flashing) pada pembasahan ini mengalir ke atas dan menghambat aliran air pendingin kebawah sehingga mengakibatkan gagalnya pendinginan pada inti reaktor tersebut
(Collier, 1972). Keadaan ini disebut LOCA (Loss of Cooling Accident). Pada kasus kegagalan pendingin pada inti reaktor, temperatur permukaan dinding inti reaktor meningkat secara tiba-tiba sehingga dapat menyebabkan lelehnya material dinding. Secara bersamaan kenaikan temperatur tersebut menyebabkan terbentuknya uap yang melebihi dari yang diizinkan untuk mempertahankan pendinginan seperti juga yang terjadi pada pipa panas (hot leg). Hot leg adalah pipa panas yang menghubungkan antara inti reaktor dengan steam generator seperti pada PLTN tipe Pressurized Water Reactors (PWR). Peristiwa flooding telah mendapat perhatian khusus dalam berbagai riset di industri nuklir terutama pada reaktor nuklir jenis PWR. Kecelakaan yang ditimbulkan oleh kerusakan fatique pada sistem perpipaan adalah kecelakaan yang dialami oleh salah satu PLTN di Jepang tahun 2004 yang akibatnya antara lain, membuat sebagian masyarakat ragu terhadap keberhasilan proyek pengembangan nuklir 
di sana. Sementara itu, kecelakaan yang disebabkan oleh sistem reaktor pendingin PLTN Fukoshima Jepang tidak berfungsi, yang menyebabkan tekanan dan suhu gas pada inti reaktor (reactor core) sangat tinggi. Tekanan dan suhu tersebut menyebabkan ledakan. Menurut Munson (2002) kecelakaan yang diakibatkan oleh kurangnya laju pendinginan pada reaktor nuklir (smal break loss of coolant accident, $S B L O C A$ ) dapat terjadi secara cepat.

Berbagai literatur yang telah terbit menunjukkan bahwa bervariasinya prediksi untuk mengetahui onset of flooding serta banyaknya parameter yang mempengaruhi. Parameter yang dimaksud adalah sifat-sifat fisis fluida dan faktor-faktor geometri saluran. Sifat-sifat fisis fluida yang mempengaruhi terjadinya flooding antara lain kekentalan dan tegangan permukaan. Kondisi lingkungan antara lain seperti gaya-gaya gravitasi yang bekerja. Sedangkan faktor-faktor geometri yang mempengaruhi terjadinya flooding antara lain diameter dan panjang saluran, kekasaran permukaan dinding saluran, dan sistem inlet dan outlet saluran (Hesteroni, 1982). Dalam kasus aliran berlawanan arah vertikal yaitu udara mengalir ke atas dan air mengalir ke bawah diperkirakan dapat terjadi fenomena hydraulic jump look like, yaitu ketika terjadi peningkatan ketebalan film secara tiba-tiba (Hesteroni, 1982). Dengan demikian, untuk mengetahui onset of flooding serta karakteristik ketebalan film dengan melibatkan waktu dan jarak perlu dikaji lebih mendalam. Pada penelitian ini aliran di dalam hot leg dimodelkan dengan aliran air ke bawah melalui pipa transparan vertikal. Air dialirkan ke bawah melewati dinding berpori sehingga diperoleh aliran film halus, sedangkan udara diinjeksikan dari sisi bagian bawah pipa secara aksial. Peningkatan laju aliran udara diprediksi dapat menyebabkan ketebalan film semakin menipis karena terbawanya sebagian air dengan aliran udara dianalogikan sebagai penipisan aliran film karena penguapan seperti halnya di dalam hot leg. Dengan demikian, hasil penelitian ini diharapkan memberikan pengetahuan dan pemahamaan tentang fenomena flooding dan karakteristik ketebalan film terutama saat terangkutnya sebagian air ke atas searah aliran udara.

Gargallo (2004) menjelaskan mekanisme flooding dan aliran reversal (reversed flow) diperlihatkan pada Gambar 1. Cairan diinjeksikan melalui dinding berpori (porous wall) yang ditempatkan pada sisi bagian atas pipa, sedangkan gas diinjeksikan dari sisi bagian bawah pipa secara aksial. Pada kecepatan gas yang rendah aliran masih dapat dikatakan pada kondisi stabil yang diperlihatkan pada Gambar 1 (a). Kenaikan laju aliran gas akan menyebabkan permukaan aliran bergelombang dan kemudian diikuti bentuk droplet yang bergerak ke atas sebagaimana diperlihatkan pada Gambar 1 (b). Bila laju aliran gas terus meningkat, maka aliran gas ini akan menghambat aliran cairan. Gejala ini dikenal sebagai permulaan flooding, dan dapat pula disebut sebagai batas aliran berlawanan arah (countercurrent flow limitation) yang diperlihatkan pada Gambar 1 (c) dan (d). Laju aliran gas yang tinggi di permukaan antarfase akan menghambat aliran cairan yang mengakibatkan laju aliran cairan semakin kecil hingga mencapai titik nol $\left(\mathrm{m}_{\mathrm{L}}=0\right)$. Pada daerah masuk air terjadi formasi droplet dengan gerakan ke atas yang diperlihatkan pada Gambar 1 (e). Saat terjadi flooding, terjadilah pengurangan laju aliran gas sedikit demi sedikit sehingga cairan mulai mengalir lagi ke bawah. Fenomena ini disebut flow reversal point yang diperlihatkan pada Gambar 1 (g). Karimi dan Kawaji (2000) melanjutkan penelitian sebelumnya, yakni dengan melakukan pengukuran ketebalan

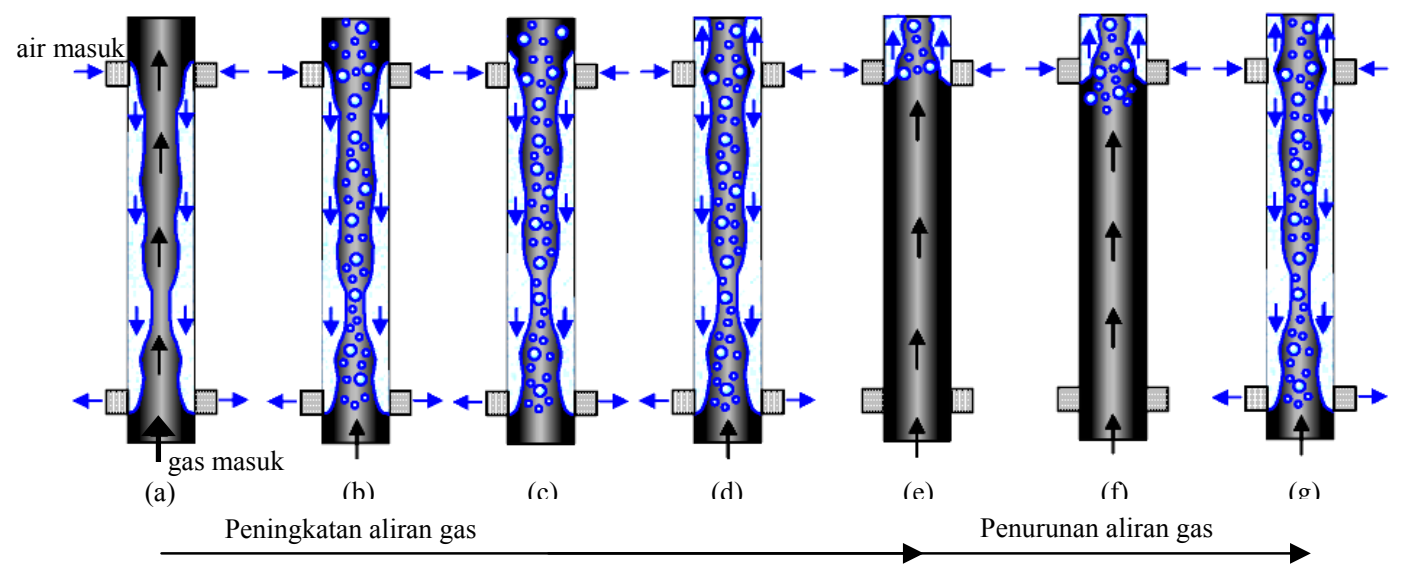

Gambar 1. Mekanisme flooding dan aliran reversal dalam pipa vertikal 
film lokal pada 5 (lima) variasi angka Reynolds air antara 2685-6903 dan angka Reynolds udara dari 0-11448. Hasil pengukuran fluktuasi ketebalan film tanpa aliran udara kemudian dibandingkan dengan fluktuasi ketebalan film saat permulaaan flooding.
Interaksi antara aliran udara dengan air semakin kuat sehingga menyebabkan fluktuasi ketebalan film meningkat hingga mencapai flooding. Untuk semua $\mathrm{Re}_{\mathrm{L}}$ hasil penelitian menunjukkan bahwa pada saat permulaan flooding, terjadi fluktuasi ketebalan film
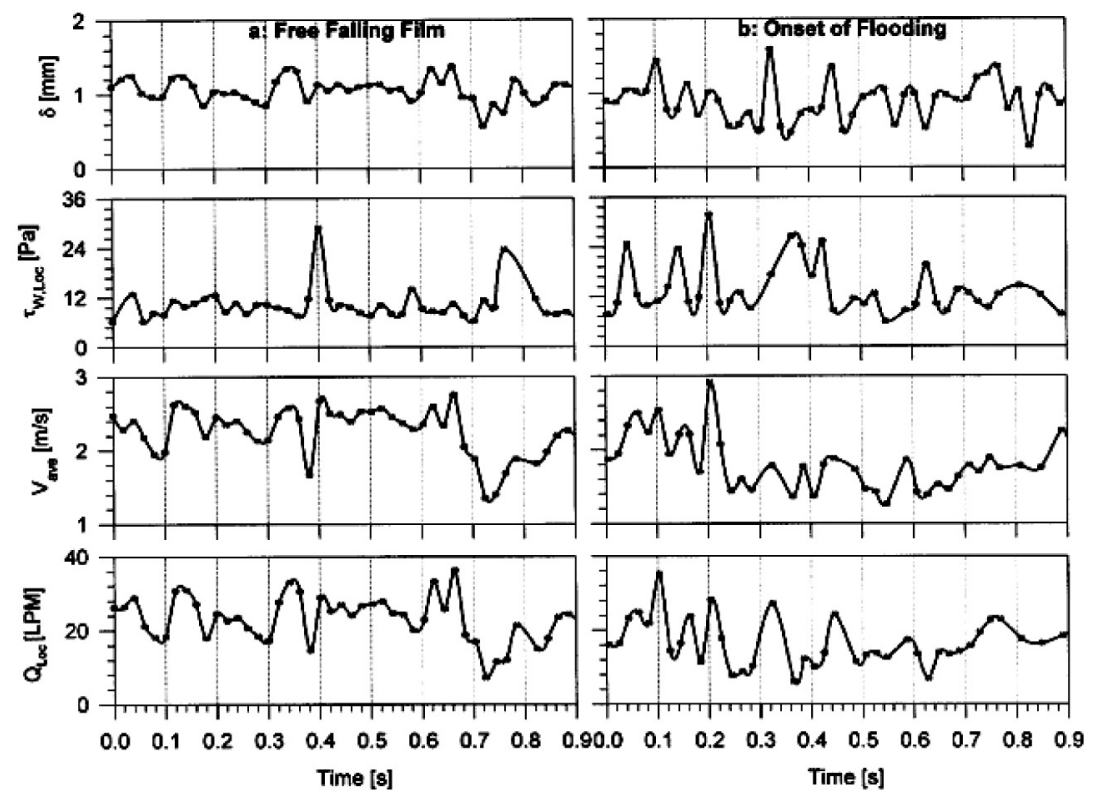

Gambar 2. Pengukuran ketebalan film air, kecepatan rata-rata dan laju aliran air lokal pada $\operatorname{Re}_{\mathrm{L}} 3348$
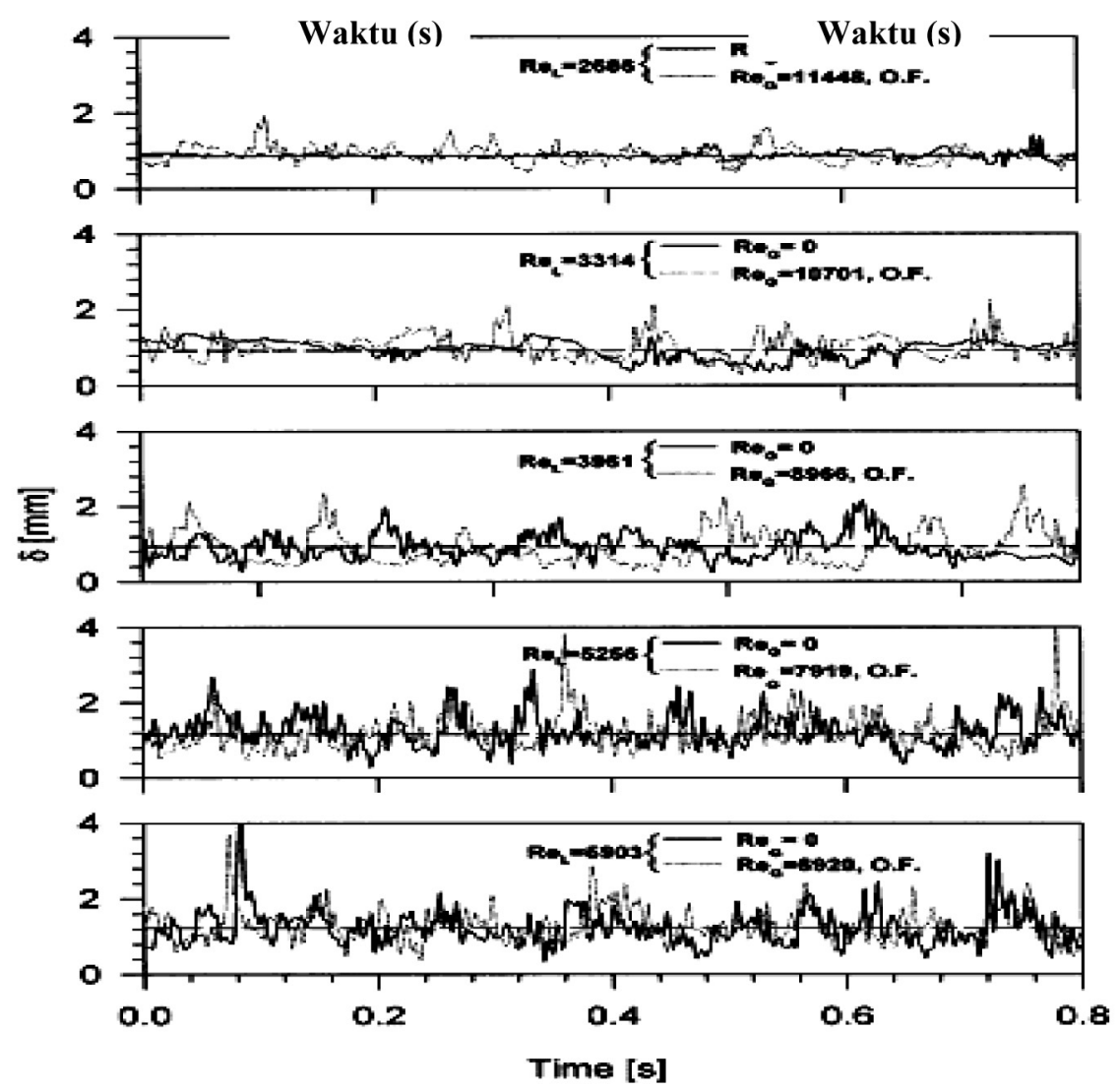

Gambar 3. Fluktuasi ketebalan film untuk aliran film jatuh bebas dan aliran film permulaan flooding 
yang lebih tinggi bila dibandingkan dengan fluktuasi ketebalan film tanpa aliran udara sebagaimana diperlihatkan pada Gambar 2.

\section{METODE}

Instalasi alat penelitian terdiri dari tiga kategori, yaitu: alat utama, alat mendukung, dan alat ukur dan pengatur. Alat utama adalah pipa transparan (seksi uji). Alat pendukung terdiri fasilitas pompa, pipa instalasi air, udara, injektor udara dan air, separator. Adapun alat ukur dan pengatur meliputi transduser tekanan, flowmeter air dan udara, manometer U dilengkapi penjebak tekanan yang berfungsi untuk menghindari aliran dua fase di dalam selang manometer, katub, kamera digital serta seperangkat alat akuisisi data. Skema seksi uji diperlihatkan pada Gambar 4.

Seksi uji yang digunakan pada penelitian ini adalah pipa transparan dari bahan fleksigelas $\left(\mathrm{d}_{\mathrm{i}}=24 \mathrm{~mm}\right.$, $\mathrm{z}=3000 \mathrm{~mm}$ ) agar dapat dengan mudah untuk mengklasifikasi pola aliran yang terjadi. Air mengalir melalui media berpori, sehingga menghasilkan aliran film yang smooth. Sedangkan udara diinjeksikan ke atas secara aksial melalui injektor udara. Untuk mengetahui karakteristik aliran film, maka pengukuran ketebalan film dilakukan pada 4 (empat) variasi angka Reynolds air $\left(\operatorname{Re}_{\mathrm{L}}\right)$, yaitu 322, 464, 630 dan 709 dengan injeksi udara dengan kecepatan dari $1,845 \mathrm{~m} / \mathrm{s}$ sampai $6,148 \mathrm{~m} / \mathrm{s}$.

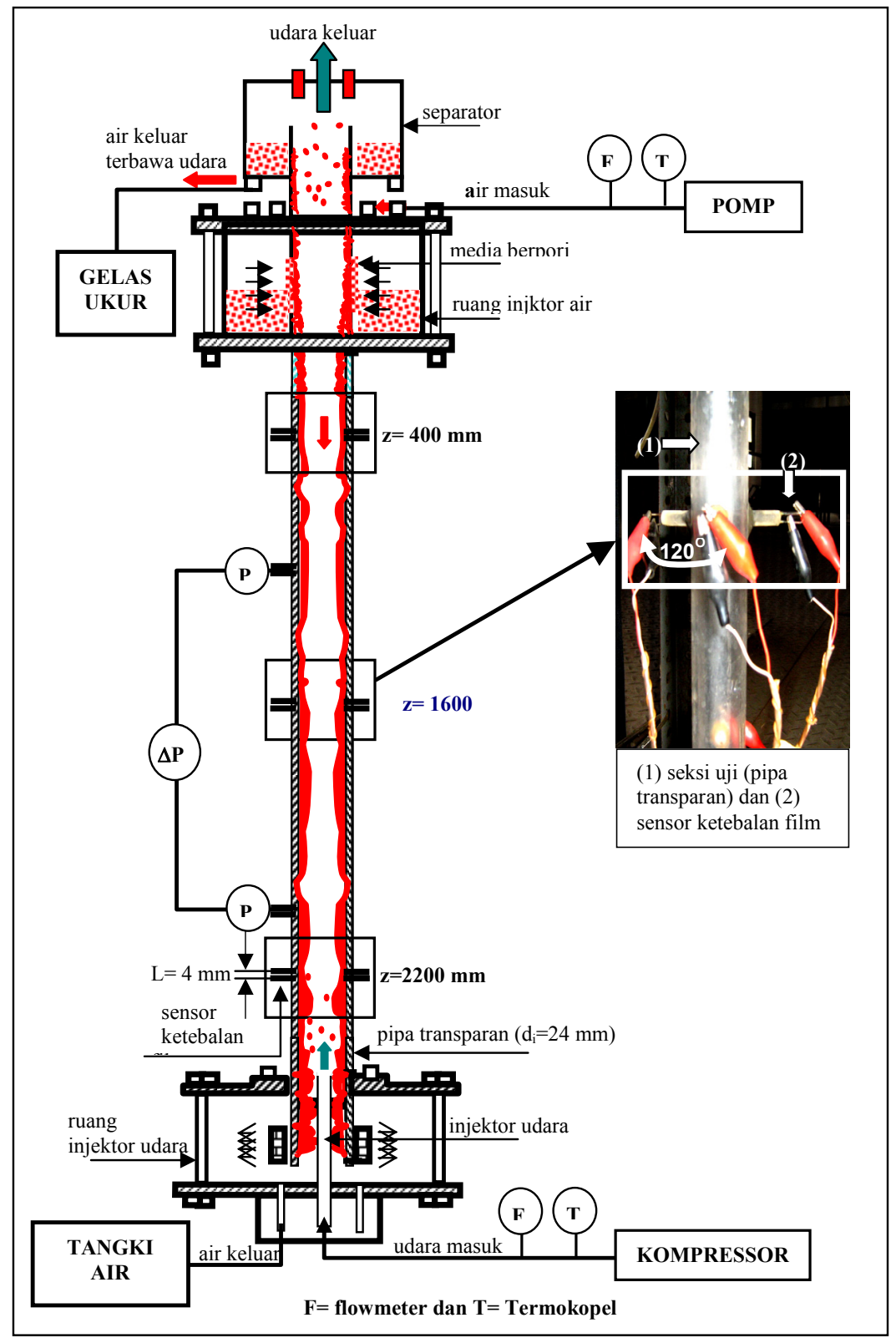

Gambar 4. Skematik Peralatan Seksi Uji 
Pengukuran ketebalan film dilakukan dengan teknik konduktansi dengan kawat paralel. Kawat ini berfungsi sebagai probe yang ditempatkan pada jarak $4 \mathrm{~mm}$ pada permukaan aliran film. Agar tidak mengganggu aliran film, maka sensor ketebalan film dipasang tepat pada permukaan dinding bagian dalam pipa. Untuk mengetahui karakteristik aliran film, maka sensor ini dipasang pada tiga lokasi, yaitu pada jarak (z) $400 \mathrm{~mm}, 1600 \mathrm{~mm}$ dan $2200 \mathrm{~mm}$ dari sisi air masuk (inlet water). Masing-masing lokasi dipasang tiga sensor secara aksial dengan jarak $120^{\circ}$ diperlihatkan pada Gambar 4. Selanjutnya, ujung sensor-sensor dihubungkan dengan alat-alat akuisisi data. Alat ini mampu merespon perubahan ketebalan film ke dalam bentuk tegangan listrik. Pengukuran ketebalan film dilakukan secara simultan dengan seperangkat alat akuisisi data, sedangkan gradien tekanan diukur dengan manometer U. Pola aliran direkam dengan kamera digital merek Canon $4 \mathrm{MP}$, untuk mengetahui debit air dan udara yang mengalir ke seksi uji dengan flowmeter. Suhu air dijaga konstan sehingga dapat diasumsikan sebagai proses adiabatik.

Selanjutnya, data-data pengukuran ketebalan film dan pengamatan pola aliran diperoleh dengan langkah-langkah sebagai berikut. Langkah pertama adalah air dialirkan dengan sebuah pompa sentrifugal pada debit 0,231 LPM $\left(\operatorname{Re}_{\mathrm{L}}=322\right)$, dibiarkan selama 10 menit sampai mencapai aliran film merata. Kemudian diinjeksikan udara pada debit sebesar $50,1 \mathrm{LPM}\left(\mathrm{J}_{\mathrm{G}}=1,845 \mathrm{~m} / \mathrm{s}\right)$. Tahap selanjutnya, pengukuran ketebalan film dilakukan dan pembacaan perbedaan ketinggian air pada manometer $\mathrm{U}$ serta merekam pola aliran. Pada debit air yang sama debit udara dinaikkan secara bertahap dari 51,6 LPM $\left(J_{\mathrm{G}}=\right.$ $1,967 \mathrm{~m} / \mathrm{s})$ sampai $166,8 \mathrm{LPM}\left(\mathrm{J}_{\mathrm{G}}=6,148 \mathrm{~m} / \mathrm{s}\right)$. Setiap peningkatan debit udara, pengukuran ketebalan film dilakukan dan pembacaan perbedaan ketinggian

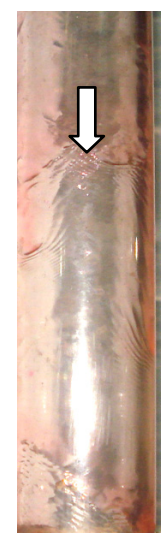

(a)

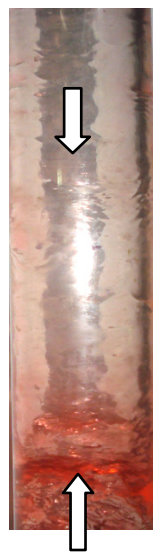

(b)

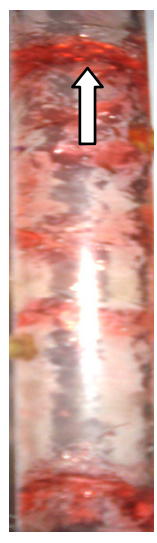

(c) peningkatan laju aliran udara

air pada manometer U serta merekam pola aliran. Dengan cara yang sama, maka langkah selanjutnya adalah menaikkan debit air secara bertahap dari 0,321 LPM $\left(\operatorname{Re}_{\mathrm{L}}=464\right), 0,503 \mathrm{LPM}\left(\mathrm{Re}_{\mathrm{L}}=630\right)$ dan $0,606 \mathrm{LPM}\left(\mathrm{Re}_{\mathrm{L}}=709\right)$ dan setiap perubahan debit air diinjeksikan udara sedikit demi sedikit hingga kecepatan udara mencapai 166,8 $\mathrm{LPM}\left(\mathrm{J}_{\mathrm{G}}=6,148\right.$ $\mathrm{m} / \mathrm{s})$. Setelah pengukuran selesai, maka investigasi pola aliran, kecepatan udara dan ketebalan film saat flooding terjadi.

\section{HASIL DAN PEMBAHASAN}

\section{Pola aliran}

Hasil pengamatan pola aliran menunjukkan bahwa pada kecepatan udara yang rendah dapat menyebabkan permukaaan aliran film smooth yang diperlihatkan pada Gambar 5 (a). Gejala terjadinya flooding selalu diawali dengan ketidakstabilan aliran film yang disebabkan oleh interaksi antara udara dan aliran film. Ketidakstabilan aliran film ditandai dengan timbulnya riak atau gelombang di permukaan film. Gelombang ini menjalar ke atas pada jarak relatif dekat terhadap sisi air keluar, dimana gaya dorong udara tidak dapat mengimbangi gaya berat air $\left(\mathrm{F}_{\mathrm{G}}<\right.$ $<\mathrm{F}_{\mathrm{L}}$ ) sehingga menyebabkan gelombang tersebut terurai menjadi droplet serta tetesan-tetesan air. Bila peningkatan laju aliran udara dimana interaksi antara udara dan air semakin kuat menyebabkan tetesan-tetesan air dan gelombang saling berinteraksi maka kemudian terbentuklah gelombang permukaan diperlihatkan pada Gambar 5 (b).

Buoyancy force pada lapisan film yang tidak bergerak dapat menyebabkan laju aliran udara di lokasi antarmuka akan turun. Sebagian lapisan film yang berinteraksi di antarmuka dapat menimbulkan pola-pola aliran. Pola aliran ini dapat menyebabkan momentun dan buoyancy force film akan berkurang.

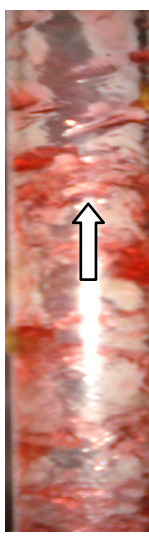

(d)

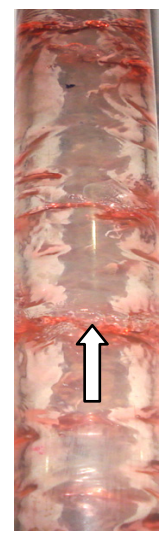

(d)

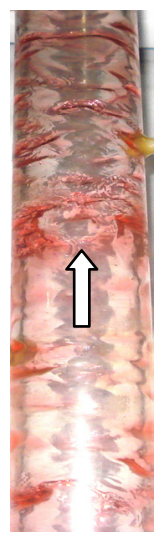

(f)

Gambar 5. Pola aliran 
Secara bertahap terjadi pertambahan energi tekanan udara (gaya dorong) untuk mengimbangi buoyancy force aliran film. Bila gaya berat lapisan film yang terdorong ke atas secara tiba-tiba dapat mengimbangi gaya dorong udara maka terjadilah gelombang. Pada kondisi ini kedua fase pada lokasi interface mempunyai kecepatan yang sama $\left(\mathrm{J}_{\mathrm{G}}=\mathrm{J}_{\mathrm{L}}\right)$. Bila kecepatan udara dinaikkan sampai mencapai kecepatan iritis, maka laju aliran film dekat batas fase perlahan-lahan mendekati nol $\left(\mathrm{J}_{\mathrm{F}}=0\right)$. Kondisi ini menyebabkan gaya berat film air $\left(\mathrm{F}_{\mathrm{F}}\right)$ menjadi sama dengan gaya dorong udara $\left(\mathrm{F}_{\mathrm{G}}\right)$. Bila $\mathrm{F}_{\mathrm{G}}>$ $\mathrm{F}_{\mathrm{F}}$, maka lapisan film yang bersinggungan dengan aliran udara terdorong ke atas dan lapisan film di dekat permukaan dinding mengalir ke bawah. Secara bersamaan pola aliran yang terjadi adalah berupa gumpalan-gumpalan film air di batas fase. Gumpalan-gumpalan tersebut menyerupai gelombang yang menyebabkan penyempitan saluran pada setiap segmen sepanjang pipa yang diperlihatkan pada Gambar 5 (c). Fenomena ini diindikasikan sebagai onset of flooding. Sedangkan Gambar 5 (d), (e) dan (f) yang memperlihatkan perambatan gelombang pasca flooding dengan frekuensi tinggi.

\section{Pengukuran Gradien Tekanan}

Hasil perhitungan gradien tekanan menunjukkan bahwa pada laju aliran udara rendah, gradien tekanan meningkat sedikit demi sedikit, tetapi saat flooding besaran ini meningkat tajam. Peningkatan gradien tekanan tersebut disebabkan oleh interaksi antara udara dengan air semakin kuat menimbulkan adanya perambatan gelombang bergerak ke atas searah dengan aliran udara. Hal ini menyebabkan penyempitan saluran.

Kurva gradien tekanan yang diperlihatkan pada Gambar 6 menunjukkan bahwa kenaikan $\mathrm{dp} / \mathrm{dz}$ pada laju aliran udara yang rendah tidak terlihat signifikan. Pola-pola aliran yang terjadi menyebabkan aliran menjadi tidak stabil. Ketidakstabilan aliran film tersebut akan memberikan fluktuasi tekanan di sembarang titik. Bila laju aliran udara meningkat dan menghambat aliran film ke bawah maka terjadi kenaikan gradien tekanan. Hal ini ditunjukkan bahwa interaksi antara air dan udara menjadi kuat yang menyebabkan penurunan momentum dan gaya badan pada lapisan film. Lapisan film yang sangat tipis menyebabkan gaya gesek di dinding, dan kecepatan aliran film sangat kecil yang mengakibatkan gradien tekanan cenderung konstan.

\section{Debit Air saat Flooding}

Kecepatan udara yang tinggi dapat mengakibatkan sebagian air terbawa ke atas. Hal ini ditunjukkan dengan terdeteksinya aliran air yang melewati injektor air. Bila air yang terbawa oleh aliran udara semakin banyak maka air yang mengalir ke seksi uji semakin kecil hingga mencapai nol $\left(\mathrm{Q}_{\mathrm{L}} \approx 0\right)$. Besarnya debit air yang terbawa oleh udara ratarata $8,676 \times 10^{-6} \mathrm{~m}^{3} / \mathrm{s}$ atau $40,94 \%$ dari debit air yang masuk pada kondisi tanpa aliran udara. Gradien

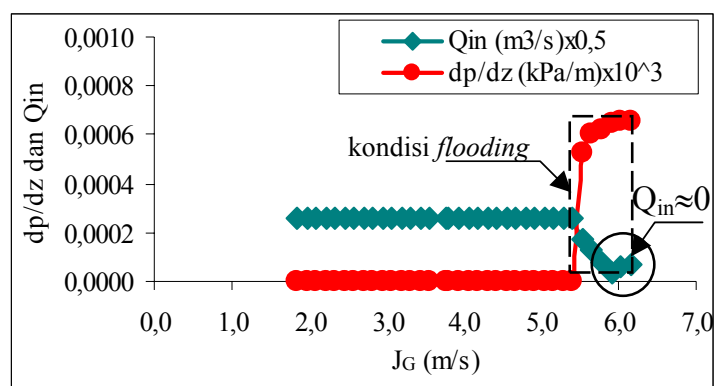

(a)

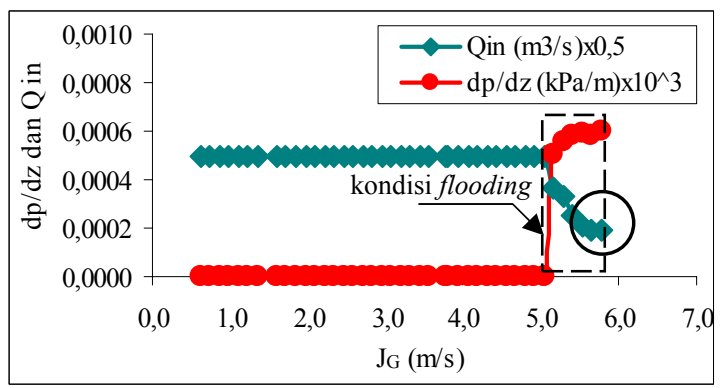

(c)

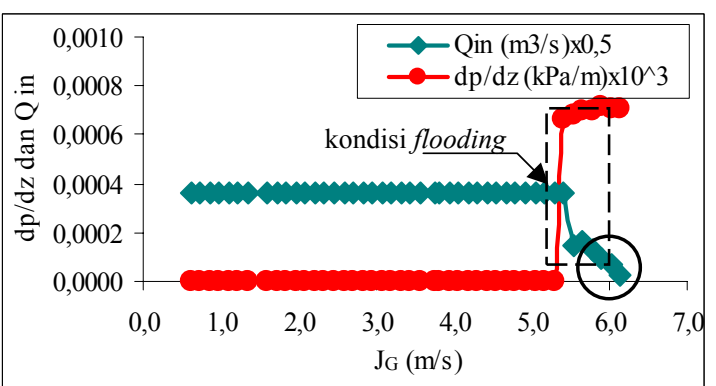

(b)

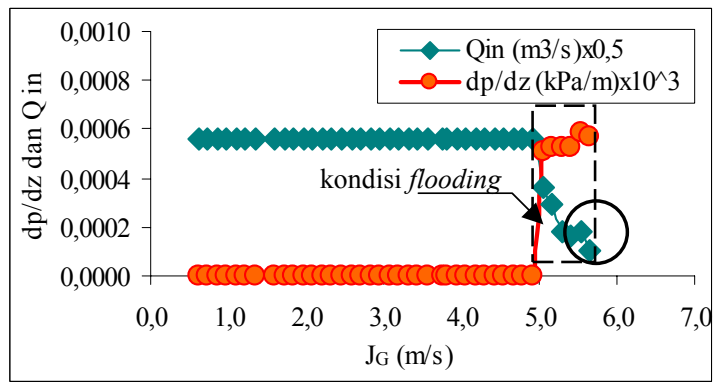

(d)

Gambar 6. Gradien Tekanan dan Debit Air Masuk Seksi Uji dengsn Peningkatan Kecepatan Udara untuk Empat Variasi $\operatorname{Re}_{\mathrm{L}}$ (a) 322, (b) 464, (c) 630 dan (d) 709 
tekanan dan debit air yang mengalir ke seksi uji ditampilkan dalam 1 (satu) grafik diperlihatkan pada Gambar 6.

\section{Hydraulic Jump LookLike (HJLL) Mekanisme hydraulic jump look like}

Gaya gravitasi adalah gaya yang mengakibatkan air mengalir ke bawah karena beratnya. Pada kondisi aliran tunak dan berkembang penuh, komponen dari gaya berat yang searah dengan aliran disetimbangkan oleh gaya geser di dinding. Untuk aliran cincin (annular flow) dalam pipa, terdapat permukaan bebas yang dapat menambah jenis dan fenomena aliran. Permukaan bebas ini yang memungkinkan aliran film dapat bergerak ke lokasi atau daerah permukaan bebasnya. Lapisan film mengalir di permukaan pipa dan udara mengalir di tengah-tengah pipa sehingga memungkinkan terjadinya pola-pola aliran yang mempengaruhi perilaku ketebalan film terhadap waktu (t) dan jarak (z).

Perubahan ketinggian air di dalam saluran terbuka dapat digolongkan menjadi dua kategori pertama perubahan ketinggian air bervariasi dengan sangat cepat (rapidly varying flow) dan terjadi pada jarak relatif dekat kedua adalah perubahan ketinggian air bervariasi secara bertahap (gradually varying flow) atau perubahan secara perlahanlahan terhadap jarak. Perubahan-perubahan tersebut dapat dianalogikan sebagai peningkatan ketebalan film secara tiba-tiba pada jarak lebih dekat dari sisi keluar air. Kondisi ini dapat terjadi saat pengangkatan sebagian film air. Ketebalan film dapat juga berubah dari ukuran yang tipis menjadi ukuran yang lebih tebal yang disebabkan oleh laju aliran udara yang mampu memberikan hambatan yang cukup signifikan. Hambatan aliran yang diberikan menyebabkan aliran film bergerak lambat. Fenomena ini dapat disebabkan adanya separasi pada daerah tertentu di batas fase yang memungkinkan terjadinya aliran balik atau osilasi pada permukaan bebas. Olakan aliran pada posisi dekat injektor udara atau sisi bagian bawah saluran dapat pula memberikan pengaruh terhadap ketebalan film yang cukup besar.

Permukaan bebas dapat terdistorsi menjadi pola-pola aliran yang selalu berkaitan dengan gelombang-gelombang permukaan. Gelombang tersebut cenderung mendominasi di permukaan film. Ada gelombang dengan frekuensi rendah, yaitu jarak antara puncak gelombang yang relatif panjang, dan frekuensi tinggi bila jarak antara puncak gelombang relatif lebih pendek. Gelombang tersebut akan mempengaruhi karakterisistik aliran, terutama perubahan ketebalan film terhadap waktu dan jarak.
Karakteristik aliran film di dalam pipa vertikal pada penelitian ini diamati bahwa pada kondisi tertentu ketebalan film bisa berubah secara cepat pada jarak relatif pendek tanpa adanya perubahan laju aliran film maupun laju aliran udara. Perubahanperubahan ini dapat diperkirakan sebagai sebuah diskontinuitas dalam permukaan bebas $(\mathrm{dy} / \mathrm{dz}=\infty)$. Konfigurasi diskontinuitas yang teramati ini dapat disebut hydraulic jump look like, yakni pola aliran yang menyerupai loncatan hidrolik. Diperkirakan hydraulic jump look like terjadi karena adanya konflik antara pengaruh aliran film pada sisi bagian bawah pipa dengan aliran film pada sisi bagian atas. Konflik ini disebabkan interaksi antara aliran udara dengan aliran film pada permukaan antarfase yang semakin kuat sehingga menyebabkan gradien tekanan (dp/dz) meningkat tajam. Di sisi bagian bawah saluran dapat terjadi aliran superkritis yaitu kondisi aliran air yang mempunyai nilai bilangan Froude (Fr) adalah lebih besar 1 atau $y_{2} / y_{1} \geq 1$. Sedangkan pada sisi bagian atas berada pada kondisi aliran subkritis yaitu kondisi aliran air yang mempunyai nilai bilangan Froude (Fr) adalah lebih kecil 1. Oleh karena itu, hyrdaulic jump look like memberikan mekanisme terjadinya transisi aliran dari superkritis ke aliran subkritis. Tegangan geser $\left(\tau_{\mathrm{w}}\right)$ antara aliran film dengan permukaan dinding pipa di dalam setiap segmen relatif kecil, yakni antara daerah yang mempunyai ketebalam film rendah dengan daerah yang mempunyai ketebalan film yang tinggi.

Kecepatan udara yang terus menerus turun akan diikuti dengan penurunan kecepatan aliran film sehingga mencapai kecepatan minimum. Saat mencapai minimum, tegangan geser dinding mencapai nol. Aliran film tetap mengalir ke bawah dan menghambat aliran udara ke atas sehingga menyebabkan kecepatan udara semakin rendah. Kondisi tersebut mengakibatkan gradien tekanan meningkat tajam, dan tegangan geser di dinding menjadi negatif. Besaran-besaran ini mengakibatkan pembalikan arah aliran. Peningkatan ketebalan film inilah yang didefinisikan sebagai hydraulic jump look like. Pada kondisi tersebut, tegangan geser antarmuka $\left(\tau_{i}\right)$ tidak mampu mempertahankan aliran film mengalir ke bawah, dan pembalikan arah aliran berlangsung terus, sehingga sebagian air terangkut ke atas bersama dengan udara.

\section{Klasifikasi hydraulic jump look like}

Hydraulic jump look like dapat terjadi bila ketebalan film di suatu daerah atau lokasi (z) mengalami peningkatan secara mendadak dalam waktu t detik. Klasifikasikan jenis hydraulic jump look like dapat dipahami berdasarkan bilangan Froude (Fr) atau rasio $\mathrm{y}_{2} / \mathrm{y}_{1}$ dengan $\mathrm{y}_{2}$ dan $\mathrm{y}_{1}$ adalah ketebalan 
film lokal sebelum dan saat kondisi flooding. Pada penelitian yang peningkatan ketebalan film berkisar dari $0,25 \mathrm{~mm}$ hingga $0,78 \mathrm{~mm}$ dengan rasio $\mathrm{y}_{2} /$ $\mathrm{y}_{1}=3,12$. Untuk rasio $\mathrm{y}_{2} / \mathrm{y}_{1}=3,12$, maka hyrdaulic jump look like ini termasuk klasifikasi loncatan lemah dan berosilasi. Fenomena hydraulic jump look like lokal yang menggambarkan peningkatan ketebalan film sebagai fungsi waktu (t) di suatu lokasi diperlihatkan pada Gambar 8 dan 12. Sedangkan pada Gambar 9 memberikan gambaran fenomena hydraulic jump look like pada jarak (z) atau lokasi dalam waktu (t) yang ditandai adanya peningkatan ketebalan film. Hasil pengukuran ketebalan film diperoleh rasio $\mathrm{y}_{2} / \mathrm{y}_{1}$ relatif berfluktuatif dengan nilai sebesar 1,813-7,855. Dengan demikian, klasifikasi hydraulic jump look like berada antara loncatan lemah dan loncatan tunak seimbang tidak sensitif terhadap kondisi awal.

\section{Karakteristik Ketebalan Film}

Hasil pengukuran ketebalan film $(\delta)$ pada jarak pengukuran (z) $400 \mathrm{~mm}, 1600 \mathrm{~mm}$ dan 2200 mm diperlihatkan pada Gambar 10. Peningkatan ketebalan film yang terdeteksi dapat disebabkan oleh interaksi antara udara dan aliran film yang semakin kuat menyebabkan tegangan geser meningkat. Kondisi ini, di mana ketebalan film meningkat secara tajam, diikuti dengan perambatan gelombang ke atas searah aliran udara dengan frekuensi tinggi. Hasil yang sama ditunjukkan pula oleh Karimi dan Kawaji (2000) yang menyatakan bahwa ketebalan film rata-rata di titik flooding bisa meningkat secara mendadak dan kemudian turun drastis pada kondisi flooding. Pada penelitian in teramati pula bahwa saat flooding ketebalan film meningkat hingga mencapai maksimum terjadi pada jarak $1600 \mathrm{~mm}$. Hal tersebut

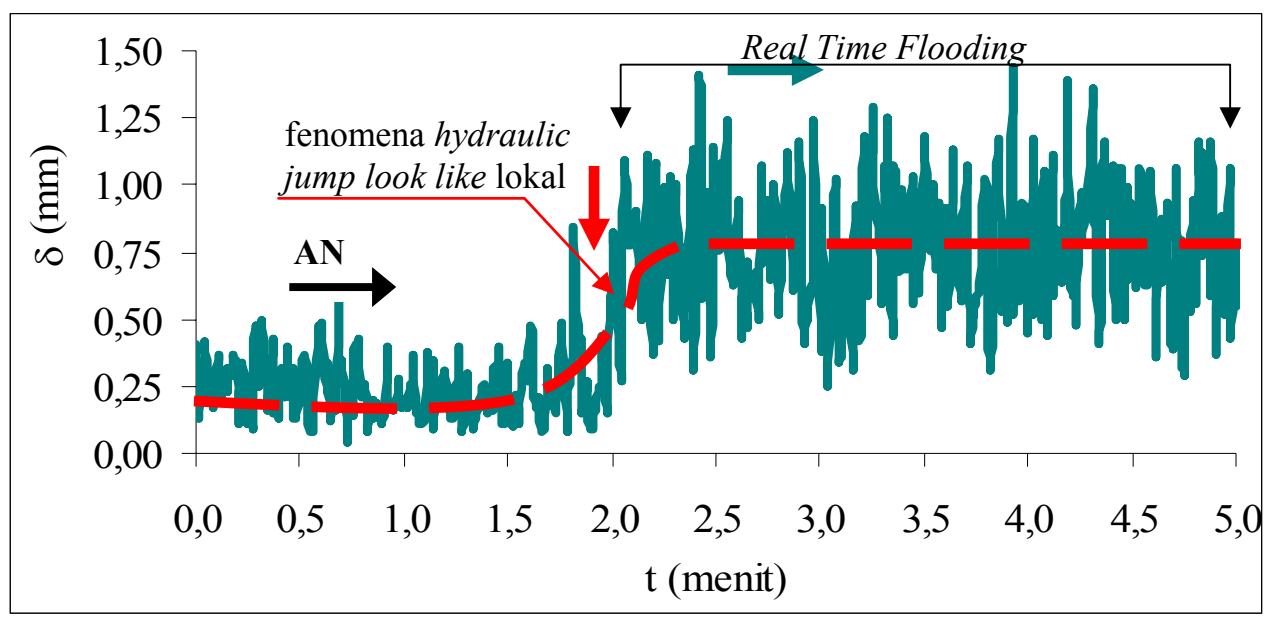

Gambar 7. Hyrdaulic jump look like lokal terhadap waktu pada $\operatorname{Re}_{\mathrm{L}} 322, \mathrm{Z}=1600 \mathrm{~mm}$ dan $\mathrm{J}_{\mathrm{GF}}=5,53 \mathrm{~m} / \mathrm{s}$

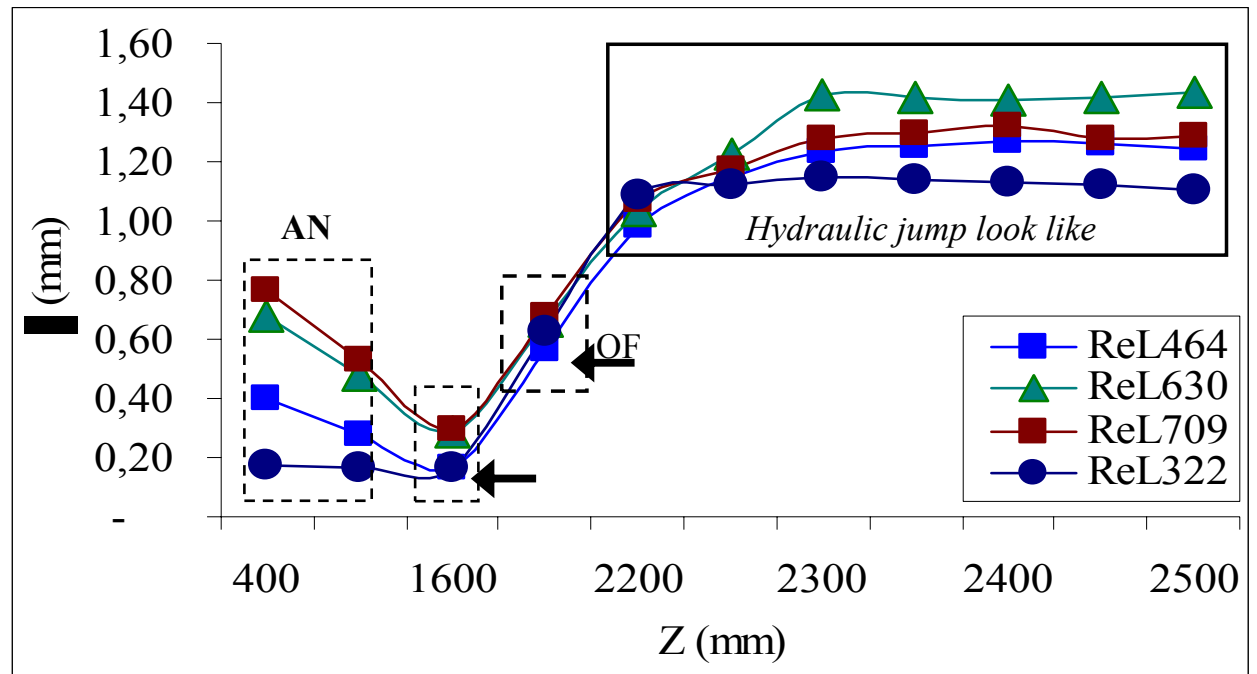

Gambar 8. Hydraulic jump look like terhadap jarak (z) 
disebabkan oleh aliran udara yang menghambat aliran film ke bawah cukup kuat, menyebabkan kecepatan aliran film menjadi lambat dan tegangan geser menjadi negatif.

Karakteristik aliran film diamati dari adanya fluktuasi-fluktuasi ketebalan film yang relatif kecil sebelum mencapai kondisi flooding. Tetapi, saat flooding fluktuasi-fluktuasi tersebut mengalami peningkatan secara signifikan. Di sisi lain, onset of flooding (OF) ditandai dengan adanya peningkatan ketebalan film secara mendadak dan terjadi lebih cepat pada sisi bagian bawah saluran yaitu pada $\mathrm{z}=$ $2200 \mathrm{~mm}$ dari sisi air masuk, bila dibandingkan pada $\mathrm{z}=400 \mathrm{~mm}$ dan $\mathrm{z}=1600 \mathrm{~mm}$, yang diperlihatkan pada Gambar 11. Fenomena ini dapat juga dibuktikan dari hasil pengukuran waktu saat pengangkatan

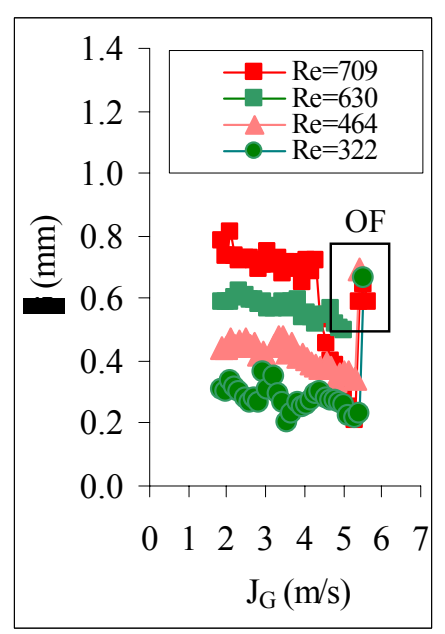

(a)

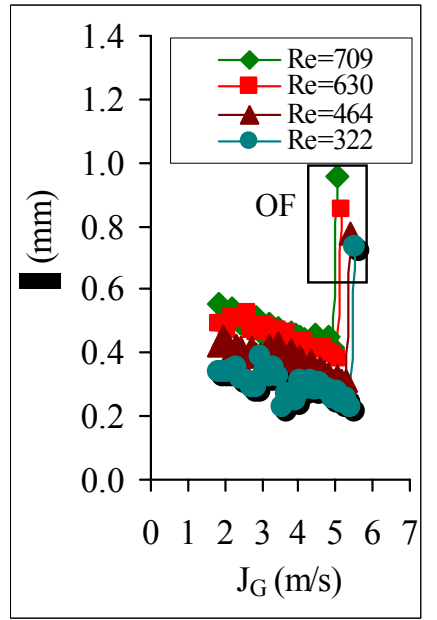

(b)

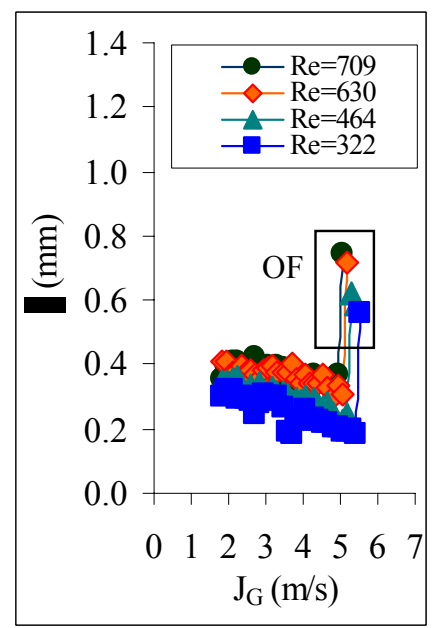

(c)

Gambar 9. Karakteristik ketebalan film pada jarak (a) $\mathrm{z}=4000 \mathrm{~mm}$ (b) $\mathrm{z}=1600 \mathrm{~mm}$ dan (c) $\mathrm{z}=2200 \mathrm{~mm}$
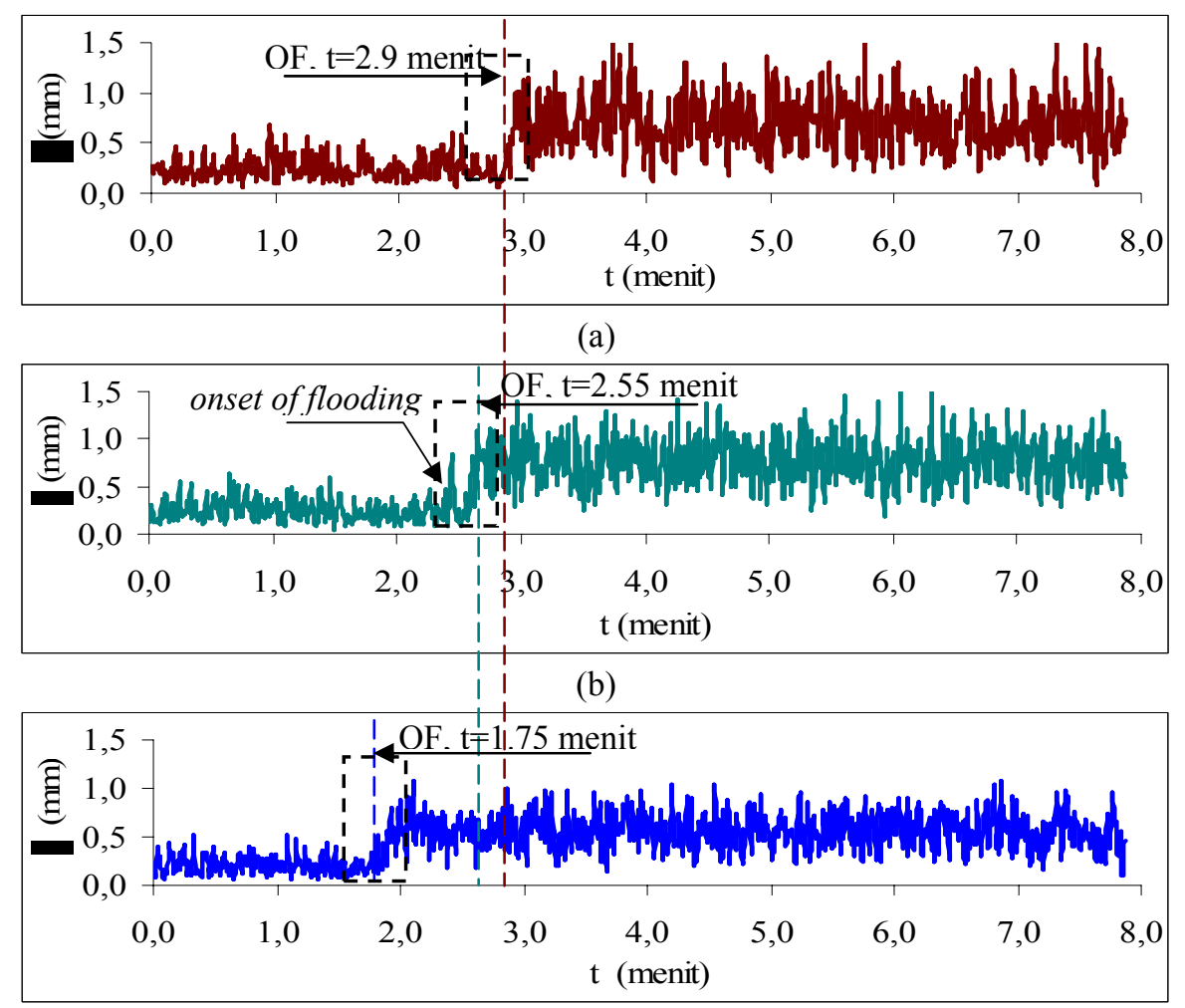

(c)

Gambar 10. Karakteristik ketebalan film dan onset flooding pada $\mathrm{Re}_{\mathrm{L}} 322, \mathrm{~J}_{\mathrm{GF}} 5.533 \mathrm{~m} / \mathrm{s}$ pada jarak pengukuran (a) $400 \mathrm{~mm}$, (b) $1600 \mathrm{~mm}$ dan (c) $2200 \mathrm{~mm}$ 

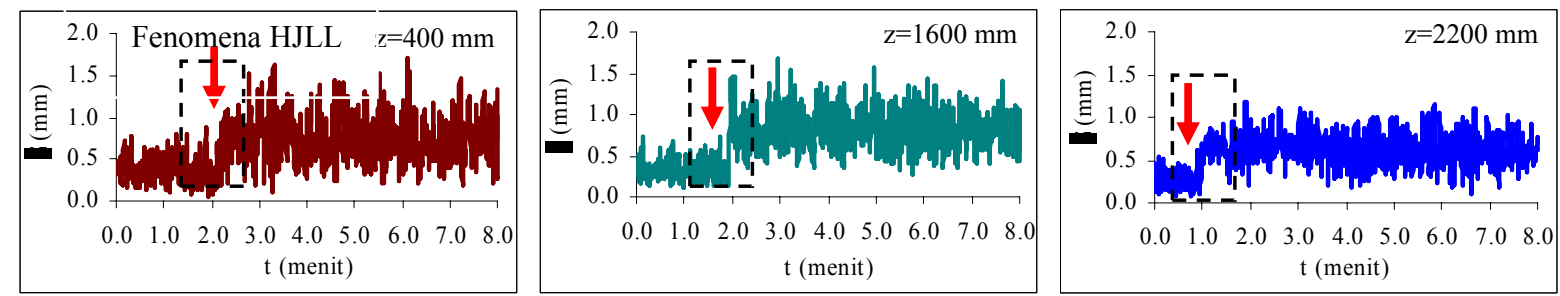

(a) $\operatorname{Re}_{\mathrm{L}} 464, \mathrm{~J}_{\mathrm{GF}} 5.411 \mathrm{~m} / \mathrm{s} \mathrm{z}=400 \mathrm{~mm}(\mathrm{t}=2.10$ menit), $\mathrm{z}=1600 \mathrm{~mm}$ ( $\mathrm{t}=1.85$ menit$)$ dan $\mathrm{z}=2200 \mathrm{~mm}$ ( $\mathrm{t}=0.95$ menit $)$
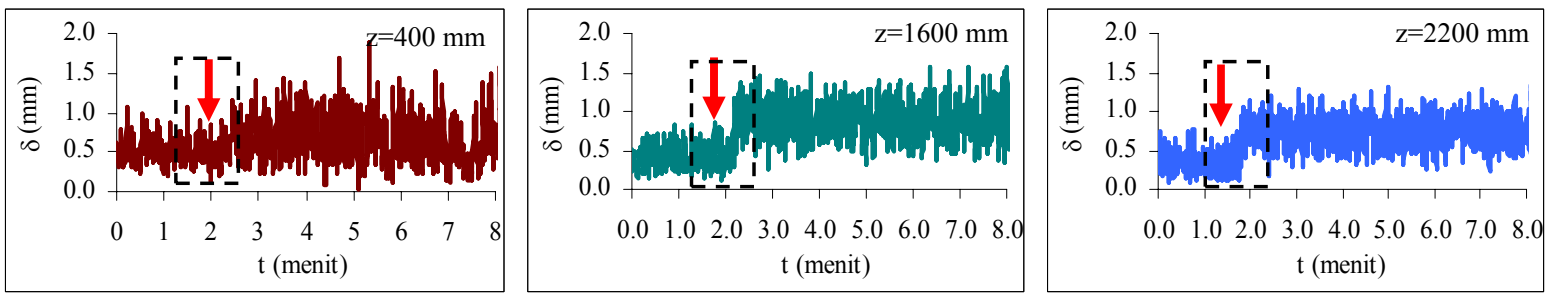

(b) $\operatorname{Re}_{\mathrm{L}} 630, \mathrm{~J}_{\mathrm{GF}} 5.165 \mathrm{~m} / \mathrm{s}$ pada $\mathrm{z}=400 \mathrm{~mm}(\mathrm{t}=2.45$ menit $), \mathrm{z}=1600 \mathrm{~mm}(\mathrm{t}=2.10$ menit$)$ dan $\mathrm{z}=2200 \mathrm{~mm}(\mathrm{t}=1.65 \mathrm{menit})$
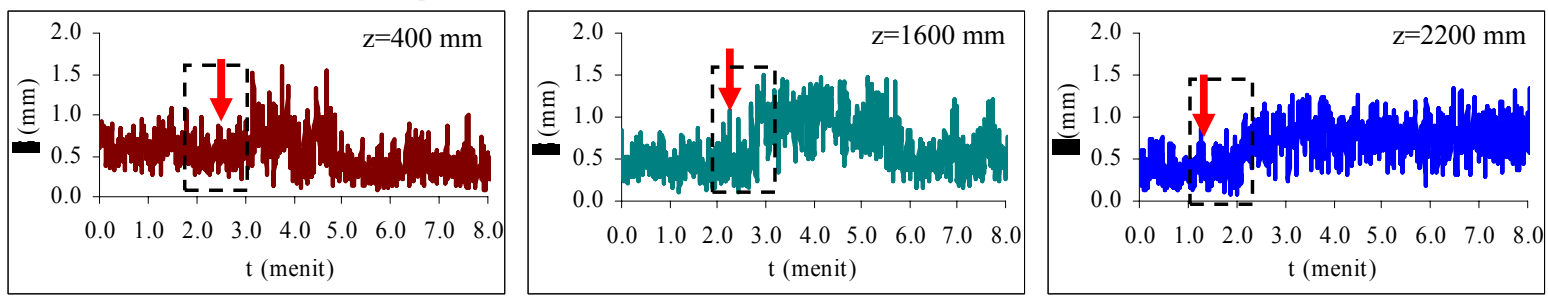

(c) $\operatorname{Re}_{\mathrm{L}} 709, \mathrm{~J}_{\mathrm{GF}} 5.042 \mathrm{~m} / \mathrm{s}$ pada $\mathrm{z}=400 \mathrm{~mm}(\mathrm{t}=3.90$ menit), $\mathrm{z}=1600 \mathrm{~mm}(\mathrm{t}=3.45$ menit $)$ dan $\mathrm{z}=2200 \mathrm{~mm}(\mathrm{t}=2.50 \mathrm{menit})$

Gambar 11. Karakteristik ketebalan film dan onset flooding pada (a) $\operatorname{Re}_{\mathrm{L}} 464, \mathrm{~J}_{\mathrm{GF}} 5.411 \mathrm{~m} / \mathrm{s}$, (b) $\operatorname{Re}_{\mathrm{L}} 630, \mathrm{~J}_{\mathrm{GF}} 5.165 \mathrm{~m} / \mathrm{s}$, $\operatorname{dan}(\mathrm{c}) \operatorname{Re}_{\mathrm{L}} 709, \mathrm{~J}_{\mathrm{GF}} 5.042 \mathrm{~m} / \mathrm{s}$

sebagian film air. Waktu pengangkatan yang dimaksud adalah $\mathrm{t}=2,9$ menit $(\mathrm{z}=400 \mathrm{~mm}), \mathrm{t}=$ 2,55 menit $(\mathrm{z}=1600 \mathrm{~mm})$ dan $\mathrm{t}=1,75$ menit $(\mathrm{z}=$ $2200 \mathrm{~mm}$ ).

\section{SIMPULAN}

Hasil pengamatan dan pengolahan data dapat disimpulkan bahwa flooding selalu diawali dengan ketidakstabilan aliran film diikuti adanya pola aliran seperti droplet, aliran acak serta tetesan-tetesan air. Saat flooding, pola aliran tersebut saling berinteraksi dan membentuk gelombang. Pada permukaan film yang bergerak ke atas searah dengan aliran udara dan gradien tekanan meningkat tajam Sementara itu, peningkatan kecepatan udara yang menyebabkan pengangkatan sebagian film air, dan teramati juga peningkatan ketebalan film secara mendadak terjadi lebih cepat pada jarak relatif lebih jauh dari sisi air masuk ( $\mathrm{z}=2200 \mathrm{~mm}$ ), bila dibandingkan pada $\mathrm{z}=400 \mathrm{~mm}$ dan $\mathrm{z}=1600 \mathrm{~mm}$. Peningkatan ketebalan film tersebut diindikasikan sebagai fenomena hydraulic jump look like.

\section{UCAPAN TERIMA KASIH}

Dalam kesempatan ini, peneliti mengucapkan terima kasih kepada Kepala dan Asisten
Laboratorium Instrumentasi dan Kontrol Industri ITN Malang yang membantu dalam pembuatan alat analisis karakteristik ketebalan film, serta Kepala dan Staf Laboratorium Perpindahan Panas dan Massa Pusat Studi Ilmu Teknik UGM atas kepercayaan penggunaan peralatan laboratorium.

\section{DAFTAR PUSTAKA}

Collier, J.G., 1972. Convective Boiling and Condensation., Edisi kedua, Mc. Graw-Hill Book International Company., New York.

Gargallo, G.M., 2004. Countercurrent Flow Limitations in Horizontal Stratified Flows of Air and Water, hoInstitut Kir Kern- and Energietechnik Programm Nukleare Sicherheitsforschung, Mitglied der Hermann von Helmltz-Gemeinschaft Deutscher Forschungszentren (HGF), ISSN 0947-8620. urn: nbn:de:0005-070184

Hesteroni, G., 1982. Handbook of Multiphase System., Mc. Graw-Hill Book International Company, pp. 61-76., New York

Karimi, G., Kawaji, M., 2000. Flooding in vertical countercurrent annular flow. Journal Nuclear Engineering and Design. 200. 95-105.

Munson, B.R., Young, D.F., Okiishi, T.H., 2002. Fundametals of Fluid Mechanics., Edisi empat, John Wiley \& Sons, Inc., United States of America. New York. 